\title{
Three dimensional accuracy analysis of dental stone casts fabricated using irreversible hydrocolloid impressions
}

\author{
Young-Hun Joo, Jin-Han Lee* \\ Department of Prosthodontics, Daejeon Dental Hospital, Wonkwang University, Daejeon, Republic of Korea
}

Purpose: The objects of this study was to evaluate the accuracy of the dental stone casts made from alginate impressions according to storage condition and stone pouring time. Materials and Methods: Each of upper and lower impressions of dental model was taken. The dental stone models were made immediately, 10, 30, 60, 180, 360 minutes after the impressions were taken at each storage condition. 3D models were constructed by scanning the stone model using 3D laser scanner. With Reference points, positioned on digital models, linear measurements of the dimensional change were compared by 3D metrology software, $3 \mathrm{D}$ average models were made and superimposition to identify the specific site of dimensional change and to measure surface deviation $(\mathrm{mm})$. Results: Dental stone models which were made immediately after taking the impression showed the smallest linear dimensional change. As the stone pouring time was prolonged, the linear dimensional change was increased. More than 180 minutes after impression taking, linear dimensional change and surface distortion increased in the posterior molar region, regardless of the storage condition. Conclusion: For the optimum accuracy of the dental stone casts, alginate impression should be poured as soon as possible. If there were a need for storing, a humidor with $100 \%$ relative humidity must be used and be stored less than 180 minutes to fabricate the accurate dental model. (J Dent Rehabil Appl Sci 2015;31(4):316-28)

Key words: alginate impression; dimensional stability; 3D superimposition

\section{서론}

치과 치료에서 환자의 구강 내 조직을 복제한 치과용 모형을 제작하는 것은 중요한 진료 과정이다. 환자의 구 강 내에서 치과 기공물이나 장치를 직접 제작할 수 없기 때문에 환자의 치아 및 주위조직을 정확히 재현하는 치 과용 모형이 필요하게 된다. ${ }^{1}$ 치과용 모형을 제작하기 위 해서는 구강 내 조직의 음형을 채득하는 과정인 인상 채 득 과정이 필요하다. 그리고 채득된 인상체에 치과용 석 고를 주입함으로써 치과용 모형을 제작할 수 있다. ${ }^{2}$ 인상 채득에 사용되는 치과용 인상재는 하이드로콜로이드, 폴

*Correspondence to: Jin-Han Lee Associate Professor, Department of Prosthodontics, Daejeon Dental Hospital, Wonkwang University, 77 Doonsan-ro, Daejeon, 35233, Republic of Korea Tel: +82-42-850-1150, Fax: +82-42-850-1115, E-mail: dentist@empas.com Received: October 23, 2015/Last Revision: October 25, 2015/Accepted: December 3,2015
리설파이드, 축중합형 실리콘, 폴리이써, 부가중합형 실 리콘이 주로 사용되고 있으며, 치과의사는 인상재의 조 작 용이성, 경제성, 선호도, 진료의 목적에 따라 사용하는 인상재를 선택하게 된다. ${ }^{3}$ 비가역성 하이드로콜로이드인 알지네이트는 경화시간이 빠르고 가격이 저렴하며, 취급 과 조작이 용이한 장점이 있어 예비 인상, 진단 모형이나 대합치 모형을 제작하기 위한 인상재로서 임상에서 가장 많이 사용되는 인상재이다. ${ }^{4}$

알지네이트 인상재는 용해성 알긴산 나트륨염이 황산 칼슘 이수염과 반응하여 불용성의 침전반응으로 겔( $(\mathrm{gel})$ 화가 진행된다. 알지네이트 분말과 물을 혼합하면 수 분 
이내에 비가역적인 겔의 형태가 되고, 생성된 하이드 로콜로이드 겔은 치과용 인상재로 사용할 만한 충분한 강도와 탄성변형을 갖는다. 하이드로콜로이드 겔의 약 $85 \%$ 가 수분이기 때문에 겔의 수분함량이 인상재의 크 기 안정성에 크게 영향을 미친다. ${ }^{5}$ 공기에 노출된 인상 체의 표면에서 수분이 소실되어 수축하는 이액현상이 나, 물과 접촉한 상태에서 수분을 추가로 흡수하여 팽창 되는 팽윤현상이 발생할 수 있기 때문에 정확하게 채득 된 인상체라 할지라도 부적절하게 보관하거나 석고를 주입하는 시간이 지체된다면 변형이 발생한다. ${ }^{6}$

알지네이트 재료의 특성상 보관 조건과 석고 주입시 간에 따라 인상체의 크기 변화가 다른 인상재에 비하여 크게 나타나기 때문에, 크기 변화에 따른 모형의 정확 도에 대한 연구가 많이 진행되어 왔다. 과거의 연구에서 Rudd 등은 하이드로콜로이드 인상재는 적절한 보관 방 법이 없기 때문에 인상 채득하여 즉시 모형을 제작하도 록 하였고, Eissmann 등 은 즉시 모형을 제작하지 못하 는 경우에는 최대 30 분까지는 항습조에 보관할 수 있다 고 하였다. 그러나 점차 알지네이트의 물성이 향상되면 서 Erbe 등 ${ }^{9}$ 은 알지네이트 인상체는 즉시 석고를 주입해 야 하지만, 항습조에 4시간까지 보관할 수 있다고 하였 고, Walker 등 ${ }^{10}$ 은 연장된 보관 시간을 갖는 새로 개발된 알지네이트 인상재를 사용할 경우에는 100시간까지도 유의한 크기 변화를 보이지 않고 보관이 가능함을 보고 하였다. 알지네이트 인상재를 사용하여 제작된 모형의 정확성에 대한 연구는 실험에 사용된 알지네이트 인상 재의 제조회사, 보관 방법과 석고 주입 시간과 실험 설 계에 따라 서로 상이한 결과를 보였지만, 대부분의 연구 에서 알지네이트 인상체에 즉시 석고를 주입할 것을 추 천하고 있다. 그리고 즉시 석고를 주입하지 못하는 경우 에는 $100 \%$ 상대 습도의 항습조에 보관하며, 보관 시간 은 최소한으로 해야 인상체의 변형을 최소화 할 수 있다 고 하였다. ${ }^{11}$

인상재의 크기 안정성에 대한 연구를 진행하는 실험 방법에는 주모형으로 단순화된 기둥모형을 사용하거나 악궁의 형태를 재현한 치과용 모델을 사용하는 방법이 있다. 단순화된 기둥모형을 주모형으로 사용하는 실험 은 인상을 채득하고 모형을 제작하여 기준점 간의 거리 를 직접 캘리퍼스로 측정하거나, ${ }^{12}$ 영상 분석 장치를 이 용하여 측정하는 방법이 사용된다. ${ }^{13}$ 이러한 실험 방법 은 단순화된 실험으로 오차가 발생할 수 있는 변수가 적 어 정확한 실험이 가능하지만 인상재 자체의 물성에 국
한된 자료만을 얻을 수 있었다. 악궁의 형태를 재현한 주모형을 사용하는 실험은 다양한 변수가 존재하지만 구강 내 상태와 유사한 조건을 부여하여 임상에 유용한 자료가 될 수 있다. 주모형의 인상을 채득하여 석고 모 형을 제작한 후, 모형 상에 설정된 참고점 간의 거리를 직접 캘리퍼스를 이용하거나, ${ }^{14}$ 영상 분석 장치를 이용 하여 측정할 수 있다. ${ }^{15}$ 최근에는 디지털 치의학이 발전 함에 따라서 석고 모형을 디지털 스캔을 통하여 데이터 화하고 프로그램 상에서 길이를 측정하는 방법도 이용 되고 있다. ${ }^{16}$ 삼차원 디지털 모델에서 거리를 측정하는 방법은 정확하고, 측정자에 따른 변위가 적어 재현성이 높기 때문에 교정 분석에서 많이 사용되고 있다. ${ }^{17}$

그러나 이러한 기존의 연구들은 석고 모형 상에서 참 고점 간의 거리 차이로 모형의 변형률을 평가하였기 때 문에 모형에 발생된 변형의 크기와 부위에 대한 연구는 부족하였다. 본 연구에서는 보관 조건이나 석고 주입 시 간에 따라 알지네이트 인상체로부터 제작된 석고 모형 의 정확도를 평가하기 위하여 삼차원 디지털 분석을 이 용한 참고점에서의 거리 측정에 따른 변형률과 중첩을 통한 표면 변위의 크기와 부위를 확인하고자 하였다.

\section{연구 재료 및 방법}

\section{1. 주모형}

인상을 채득할 주모형은 구강 내 치아와 악궁을 재현 한 치과용 모형(Dental model D51DP-500A-M, Nissin dental, Kyoto, Japan)을 이용하였다. 인상 채득 시에 각 인상체가 주모형과 동일한 간격을 가질 수 있도록 주 모형을 인상 채득을 위한 장치를 제작(Samjin industry, Chungju, Korea)하였다. 상악과 하악의 주모형 전방 과 후방에 인상용 트레이의 위치를 고정하는 3개의 수 직 기둥을 설치하였다(Fig. 1A). 인상용 트레이(Micron perforated adult EL tray, Micron Dental, Seoul, Korea) 의 후방에는 수직 기둥의 정지점에 위치되는 금속판을 추가로 용접하여 부착하여, 인상용 트레이의 전방과 후 방에 부착된 금속판은 인상용 트레이가 인상 채득 장치 에 수직으로 삽입, 제거되도록 하였다. 수직 기둥의 정 지점 상부에 나사를 조여 주모형과 인상용 트레이 사이 의 알지네이트 인상재가 일정한 두께를 유지하면서, 인 상재가 경화되는 동안 인상용 트레이에 일정한 압력을 유지할 수 있도록 하였다(Fig. 1B). 


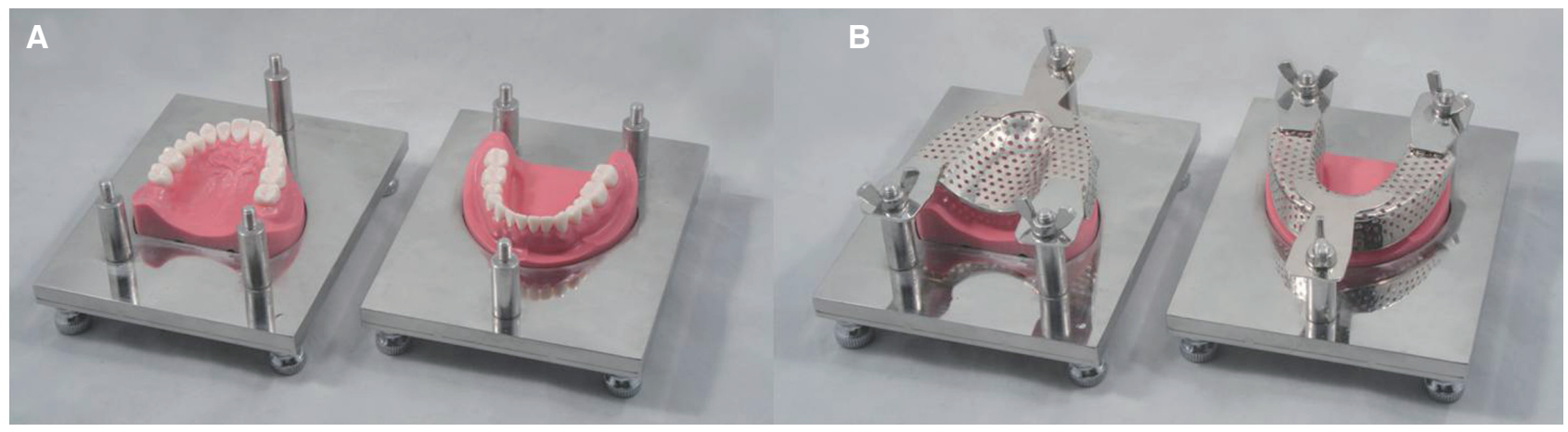

Fig. 1. Impression taking device. (A) Master model fixed on a metal plate, (B) Positioning rod hold the impression tray tight.

\section{2. 인상채득}

알지네이트 인상재는 Aroma Fine Plus (GC Co., Tokyo, Japan) normal setting type을 사용하였다. 제조 사의 지시에 따라서 혼수 비를 맞추어, 알지네이트 인상 재 진공혼합기(Tornado, Shinhung, Seoul, Korea)를 이 용하여 혼합하였다. 알지네이트의 혼합시간은 14 초였 고, 균일하게 혼합된 알지네이트를 인상용 트레이에 담 아 주모형에 위치시킨 상태에서 120 초 동안 유지하였 다. 혼합에서부터 3 분 30 초가 경과한 후에 인상체를 제 거하였으며, 제거 시 인상체의 변형을 최소화하기 위하 여 주모형에서 인상용 트레이를 단번에 제거하였다. 실 험의 일관성을 위하여 한명의 실험자에 의해서 인상채 득이 수행되었으며, 상, 하악 모형에서 보관조건과 석고 주입 시간에 따른 각 실험군 별로 각각 15 개의 인상을 채득하였다.

\section{3. 모형제작}

채득된 인상체는 실온에서 실험실 내의 공기(상대습 도 $35 \%$ ) 중에 노출되는 상태와 항습조(상대습도 100\%) 에 보관하는 조건으로 나누고, 각각 석고 주입 시간을 다르게 하였다. 석고 주입 시간은 채득 즉시, 채득 후 10 분, 30 분, 60 분, 180 분, 360 분 경과 후였다. 보관 조건과 석고 주입시간에 따라 치과용 경석고(Neo Plum stone, Mutsumi Chemical Co., Yokkaichi, Japan)를 제조사의 혼수비에 맞추어 진공 혼합한 후, 채득된 인상체에 주입
하였다. 석고가 주입된 각각의 인상체는 채득 후, 인상 체를 보관하였던 실험실 내의 공기 중과 항습조에 같은 조건으로 석고가 경화되는 동안에 보관하였다.

석고를 주입하고 1시간 경과한 후에 인상체로부터 석고모형을 분리하였다. 제작된 석고 모형은 각각 치 과용 삼차원 레이저 스캐너(MyS 3D Dental Scanner, Raphabio, Seoul, Korea)를 이용하여 스캔을 시행하여 STL (sterolithography)파일을 획득하였다.

\section{4. 측정}

획득된 석고 모형의 STL 파일을 이용하여 기존의 연 구 방법에서 사용된 모형에서의 참고점 간의 길이 측정 과 삼차원 모델의 정량적인 비교를 시행하기 위하여 3D metrology software (Geomagic Control, Cary, USA)를 사용하였다. 기존의 연구와 동일한 방식으로 삼차원 디 지털 모형의 각 참고점에서 길이 측정을 시행하였다. 그 리고 주모형과 실험군의 모형을 삼차원적으로 비교하기 위하여 중첩을 시행하였다. 중첩 방법은 주모형에서 무 작위로 선택된 300 개의 지점에서 주모형과 실험군의 모 형을 정렬을 시행 한 후에, 두 모형의 일치하는 지점을 기준으로 다시 무작위로 선택된 1500 개의 지점에서 추 가로 두 모형을 정렬하는 작업이 이루어진다. 최종적으 로 두 모형이 중첩된 상태에서 표면에서 발생하는 변위 의 크기 $(\mathrm{mm})$ 를 측정하여 삼차원 비교를 시행하였다. 

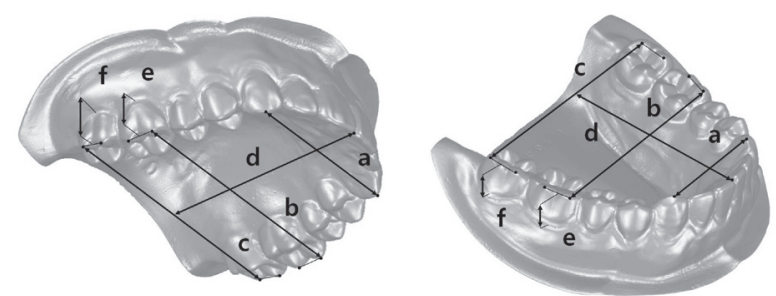

Fig. 2. Linear measurements at reference point of 3D model. $a$, inter canine distance; $b$, inter first molar distance; c, inter second molar distance; $d$, arch length; e, first molar height; f, second molar height.

1) 참고점에서 거리 측정과 변형률 계산 상악과 하악에서 견치의 절단, 제 1 대구치의 근심 협측 교두정과 제 2 대구치 원심 협측 교두정과 좌우측 중절치 의 사이에 참고점을 설정(Fig. 2)하고 거리를 측정하였 다. 측정자의 오차를 줄이기 위하여 한 명의 조사자에 의하여 측정이 이루어 졌다.

a: 견치 간 거리- 양측 견치의 교두정간 거리

$\mathrm{b}$ : 제 1 대구치 간 거리- 양측 제 1 대구치의 근심 협측 교 두정간 거리 c: 제 2 대구치 간 거리- 양측 제 2 대구치의 원심 협측 교 두정간 거리

$\mathrm{d}$ : 악궁의 길이- 양측 중절치에서 제 2 대구치를 이은 선과 만나는 수직 거리

$\mathrm{e}$ 제 1 대구치의 치관 높이- 제1대구치 근, 원심 협측교 두정을 이은 선에서 치은연의 가장 낮은 부위까지 의 수직 거리

$\mathrm{f}$ : 제 2 대구치의 치관 높이- 제 2 대구치 근, 원심 협측교 두정을 이은 선에서 치은연의 가장 낮은 부위까지 의 수직 거리

각 참고점을 기준으로 측정된 주모형의 거리를 기준 으로 실험군의 모형에서 측정된 거리를 이용하여 변형 률을 계산하였다.

\section{2) 삼차원 모형의 중첩을 통한 크기변화량 측정}

보관조건과 석고 주입 시간에 따른 각 실험군에서 제 작된 15 개 석고모형의 데이터를 정렬하여 삼차원 디지 털 모형의 평균 모형을 제작하였다. 제작된 실험군의 평 균 모형을 주모형에서 제작된 디지털 모형과 중첩을 시 행하여 전체 크기 변화량을 측정하고, 변형이 발생하는 부위를 확인하였다(Fig. 3).

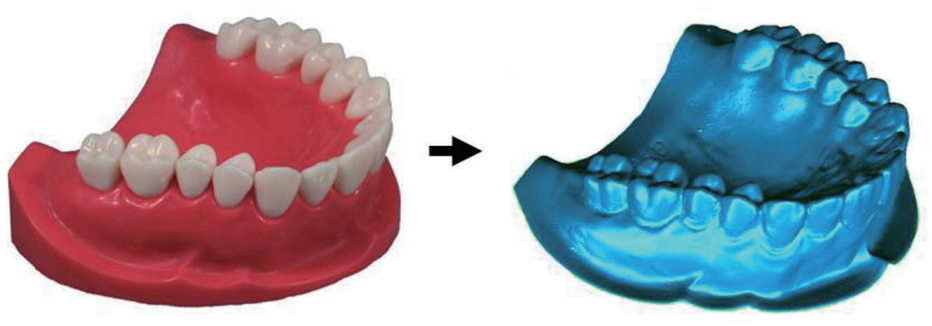

Master model
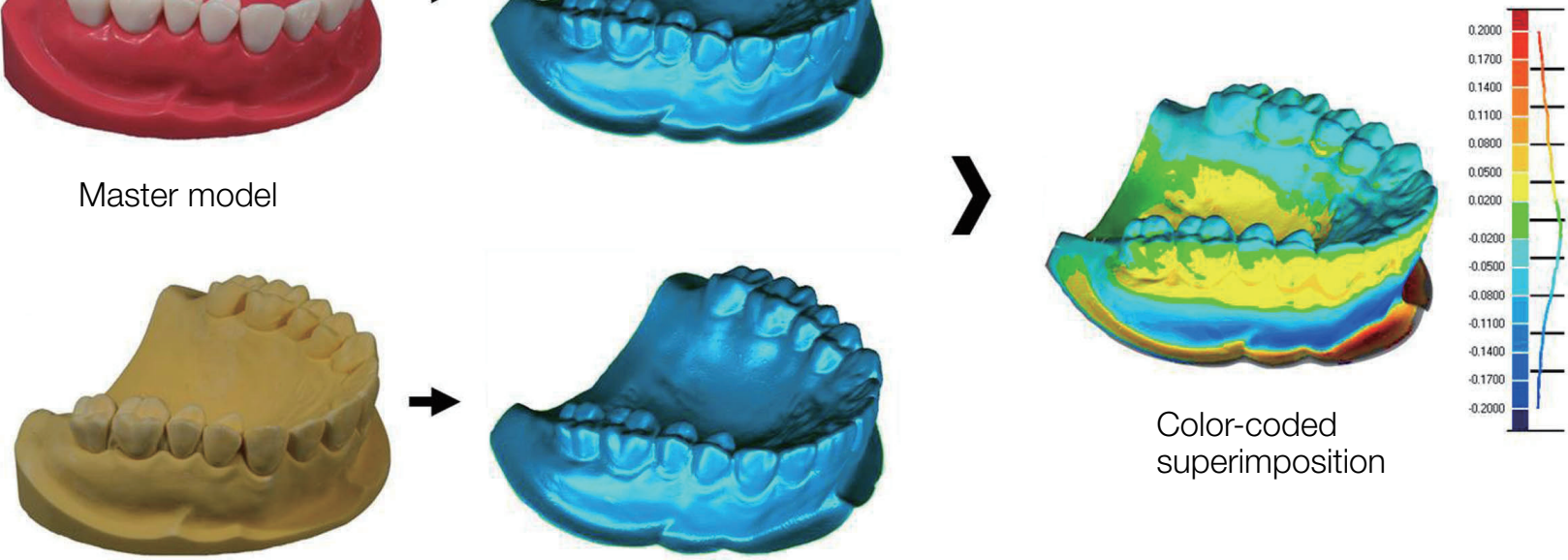

Stone model of experimental group

Fig. 3. Superimposition procedure for dimensional change analysis between master model and experimental group model. 


\section{5. 통계분석}

참고점에서 길이 측정 결과의 평균과 표준편차를 이 용하여 인상체의 보관조건과 석고 주입 시간에 따른 크 기변화의 유의성을 검증하였다. 유의성의 검증은 SPSS 통계 프로그램(SPSS 20.0 for Windows, IBM SPSS Inc., Chicago, USA)에서 이원 분산 분석(Two-way ANOVA) 을 통해 실시하였고, Turkey 다중 범위 검증법을 이용하 여 유의성을 사후 검증하였다 $(P<0.05)$.
결과

1. 보관 조건과 석고 주입 시간에 따라 알지네이트 인상체에서 제작된 석고 모형의 디지털 삼차원 거리 측정에 따른 변형률의 결과는 다음과 같다 (Table 1).

1) 견치 간 거리(a)의 변형률

인상 채득 즉시, 석고를 주입하는 경우 상악에서

Table 1. Linear dimensional change (\%) according to storage condition and stone pouring time

\begin{tabular}{|c|c|c|c|c|c|c|c|}
\hline & \multicolumn{6}{|c|}{ Storage time } \\
\hline & & Immediately & 10 minutes & 30 minutes & 60 minutes & 180 minutes & 360 minutes \\
\hline \multicolumn{8}{|c|}{ Inter canine distance } \\
\hline \multirow[t]{2}{*}{ Maxilla } & Air & \multirow{2}{*}{0.04} & 0.51 & 0.70 & 0.84 & 0.70 & 0.95 \\
\hline & Humidor & & 0.36 & 0.44 & 0.38 & 0.51 & 0.50 \\
\hline \multirow[t]{2}{*}{ Mandible } & Air & \multirow{2}{*}{-0.14} & -0.54 & -0.25 & -0.40 & -0.69 & -0.44 \\
\hline & Humidor & & -0.30 & -0.45 & -0.54 & -0.35 & -0.56 \\
\hline \multicolumn{8}{|c|}{ Inter first molar distance } \\
\hline \multirow[t]{2}{*}{ Maxilla } & Air & \multirow{2}{*}{-0.06} & 0.13 & 0.41 & 0.35 & 0.36 & 0.21 \\
\hline & Humidor & & -0.08 & 0.10 & 0.12 & 0.06 & 0.10 \\
\hline \multirow[t]{2}{*}{ Mandible } & Air & \multirow{2}{*}{0.11} & 0.28 & 0.33 & 0.35 & 0.21 & -0.14 \\
\hline & Humidor & & 0.26 & 0.17 & 0.19 & 0.40 & 0.32 \\
\hline \multicolumn{8}{|c|}{ Inter second molar distance } \\
\hline \multirow[t]{2}{*}{ Maxilla } & Air & \multirow{2}{*}{-0.23} & -0.31 & -0.39 & 0.24 & -0.32 & -0.42 \\
\hline & Humidor & & -0.25 & 0.32 & -0.45 & -0.61 & -0.51 \\
\hline \multirow[t]{2}{*}{ Mandible } & Air & \multirow{2}{*}{0.19} & 0.35 & 0.25 & 0.27 & 0.48 & 0.50 \\
\hline & Humidor & & 0.28 & 0.26 & 0.28 & 0.36 & 0.28 \\
\hline \multicolumn{8}{|l|}{ Arch length } \\
\hline \multirow[t]{2}{*}{ Maxilla } & Air & \multirow{2}{*}{-0.07} & -0.34 & 0.08 & 0.29 & 0.40 & 0.53 \\
\hline & Humidor & & -0.10 & -0.13 & -0.03 & 0.25 & 0.09 \\
\hline \multirow[t]{2}{*}{ Mandible } & Air & \multirow{2}{*}{0.82} & 0.92 & 1.01 & 1.12 & 2.48 & 3.27 \\
\hline & Humidor & & 0.99 & 0.91 & 0.84 & 1.85 & 1.95 \\
\hline \multicolumn{8}{|c|}{ First molar height } \\
\hline \multirow[t]{2}{*}{ Maxilla } & Air & \multirow{2}{*}{-0.42} & 1.79 & 2.93 & 2.78 & 1.68 & 1.89 \\
\hline & Humidor & & -0.86 & 3.14 & 2.23 & 1.82 & 1.97 \\
\hline \multirow[t]{2}{*}{ Mandible } & Air & \multirow{2}{*}{3.50} & 3.87 & 4.23 & 4.41 & 5.95 & 6.55 \\
\hline & Humidor & & 3.65 & 3.92 & 4.11 & 5.57 & 5.55 \\
\hline \multicolumn{8}{|c|}{ Second molar height } \\
\hline \multirow[t]{2}{*}{ Maxilla } & Air & \multirow{2}{*}{-0.11} & 0.38 & -1.19 & -1.25 & -1.40 & -1.42 \\
\hline & Humidor & & 0.30 & 0.97 & 0.73 & 0.04 & 0.52 \\
\hline Mandible & Air & ת & 2.92 & 3.75 & 3.64 & 4.21 & 5.17 \\
\hline & Humidor & 2.13 & 2.85 & 3.42 & 3.03 & 3.13 & 3.70 \\
\hline
\end{tabular}


$0.04 \%$, 하악에서 $-0.14 \%$ 로 가장 낮게 나타났다. 보관 조 건이나 석고 주입 시간에 따라 상악에서는 유의한 차이 를 보이지 않았다. 하악에서는 보관 조건에 따라서는 유 의한 차이가 없었지만, 석고 주입 시간에 따라서는 60 분 이후부터는 유의한 차이를 나타냈다

\section{2) 제 1 대구치 간 거리(b)의 변형률}

인상 채득 즉시, 석고를 주입하는 경우 상악에서 $-0.06 \%$, 하악에서 $0.11 \%$ 로 가장 낮게 나타났다. 보관 조 건에 따라 공기 중에 보관한 경우에서 유의한 차이를 나 타냈고, 석고 주입 시간에 따라서는 하악에서만 360 분 에서 유의한 차이를 나타냈다.

3) 제 2 대구치 간 거리 (c)의 변형률

인상 채득 즉시, 석고를 주입하는 경우 상악에서 $-0.23 \%$, 하악에서 $0.19 \%$ 로 가장 낮게 나타났다. 보관 조 건과 석고 주입시간에 따라서는 유의한 차이를 보이지 않았다.

\section{4) 악궁의 길이(d) 변형률}

인상 채득 즉시, 석고를 주입한 상악에서 $-0.07 \%$, 하 악에서 $0.82 \%$ 로 가장 낮게 나타났다. 상하악 모두에서 보관 조건에 따라서는 유의한 차이를 보이지 않았으나, 석고 주입 시간에 따라서는 180 분 이후에서 유의한 차 이를 나타냈다.

\section{5) 제 1 대구치의 치관 높이(e) 변형률}

인상 채득 즉시, 석고를 주입하는 경우 상악에서 $-0.42 \%$, 하악에서 $3.5 \%$ 로 가장 낮게 나타났다. 보관 조
건과 석고 주입 시간은 상악에서는 유의한 차이를 보이 지 않았고, 하악에서는 석고 주입 시간에 따라서 180 분 이후에서 유의한 차이를 나타냈다.

6) 제 2 대구치의 치관 높이(f) 변형률

인상 채득 즉시, 석고를 주입하는 경우 상악에서 $-0.11 \%$, 하악에서 $2.73 \%$ 로 가장 낮게 나타났다. 보관 조 건과 석고 주입 시간은 상악에서는 유의한 차이를 보이 지 않았고, 하악에서는 석고 주입 시간에 따라서 60 분 이후에서 유의한 차이를 나타냈다.

\section{2. 주모형과 각 실험군의 평균 모형의 중첩에 따른 표 면 변위량를 상악과 하악에서 각각 측정하였다.}

\section{1) 상악 모형}

상악 주모형과 각 실험군의 삼차원 디지털 모형을 중 첩한 결과, 알지네이트로 인상 채득 즉시 석고 모형을 제작한 경우 표면 변위량이 $0.02 \mathrm{~mm}$ 로 가장 낮게 나타 났다. 석고 주입 시간에 따른 결과에서 시간에 따라 표 면 변위량은 증가하며, $100 \%$ 상대습도의 항습조에 보 관한 경우가 $35 \%$ 상대습도의 공기 중에 보관한 경우에 비해 표면 변위량이 모두 낮게 나타났다. 항습조에 보 관한 경우 10 분과 30 분의 표면 변위량은 $0.06 \mathrm{~mm}, 0.04$ $\mathrm{mm}$ 로 30 분의 표면변위가 10 분에 비해서 낮게 나타났 다. 표면 변위는 주로 제 2 대구치 협측 치은부위에서 가 장 크며, 180 분이 경과하면 보관 조건 모두에서 교합면 에 변화가 발생한다. 실온에서 360 분을 보관한 경우에 서 구치부 교합면의 가장 큰 변화를 나타냈다(Fig. 4-6).

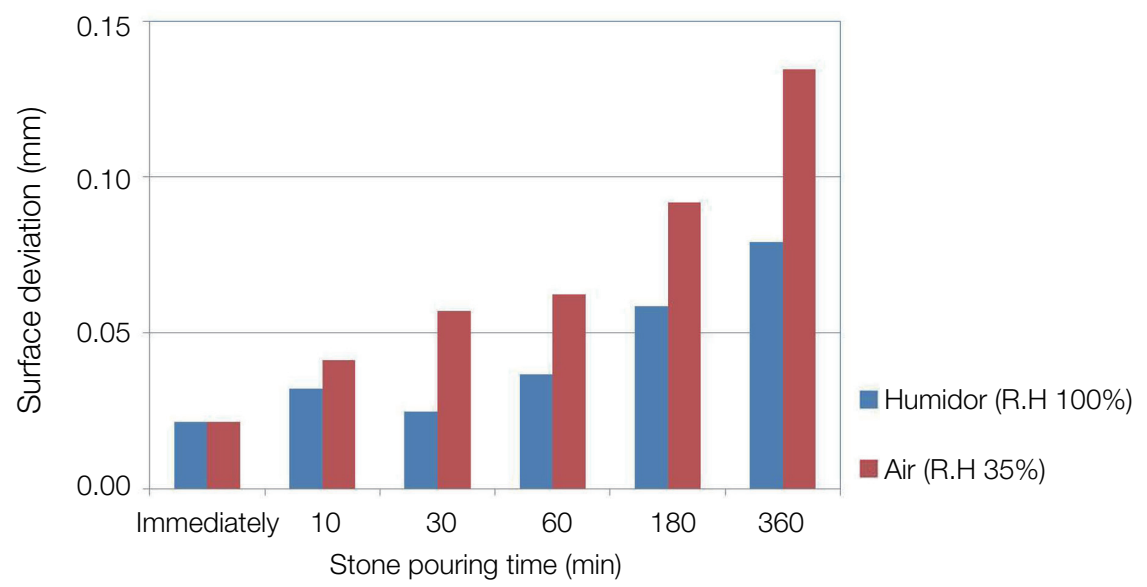

Fig. 4. Maxillary surface deviation according to storage condition and stone pouring time. $\mathrm{R} . \mathrm{H}$, relative humidity. 

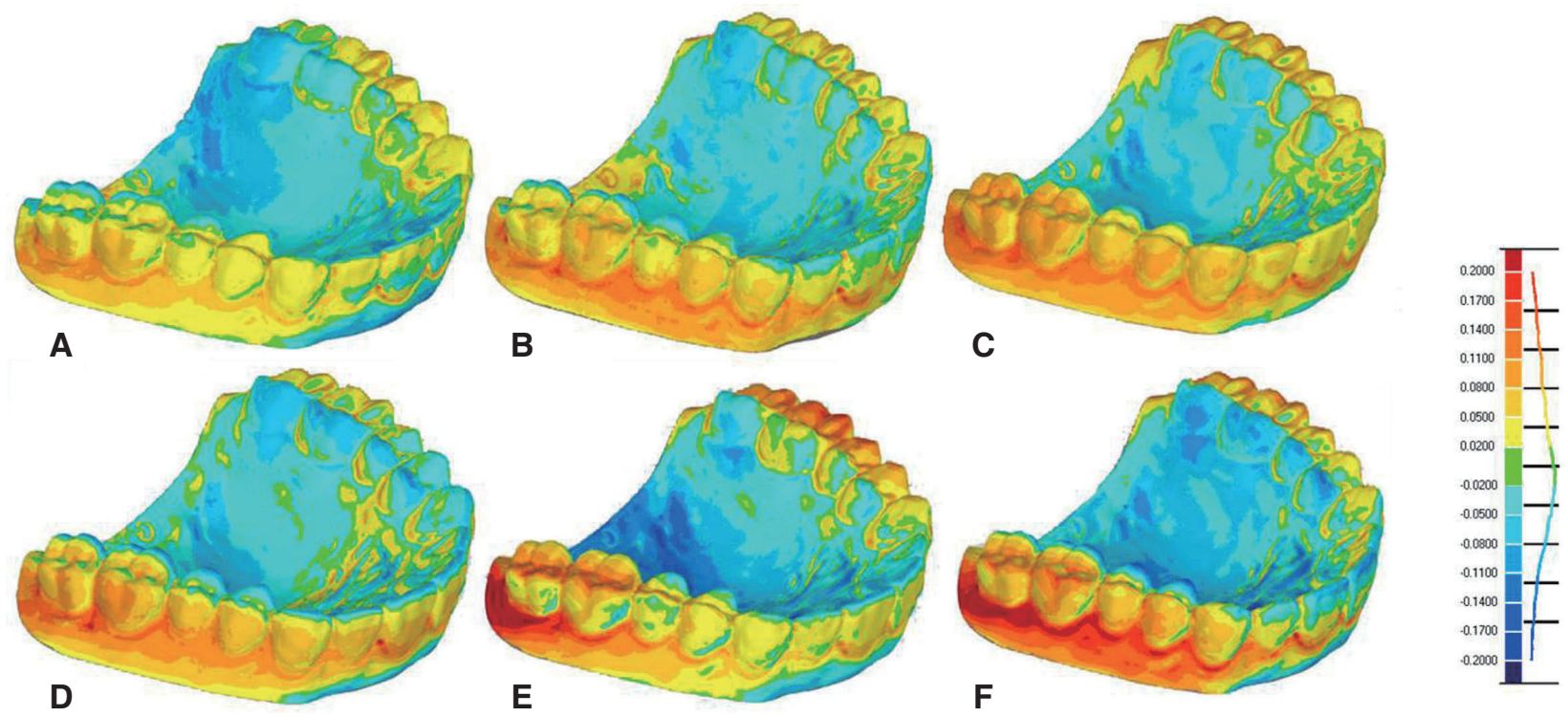

Fig. 5. Maxillary surface deviation of stone pouring time on relative humidity $100 \%$ humidor. (A) Immediately, (B) 10 minutes, (C) 30 minutes, (D) 60 minutes, (E) 180 minutes (F) 360 minutes.
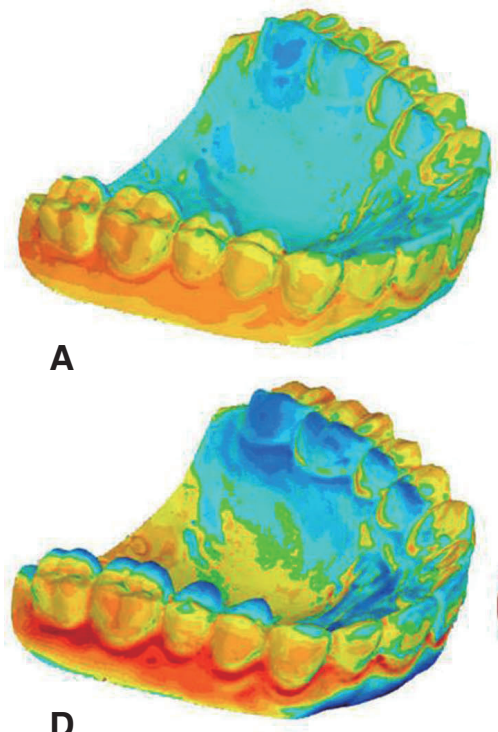

D

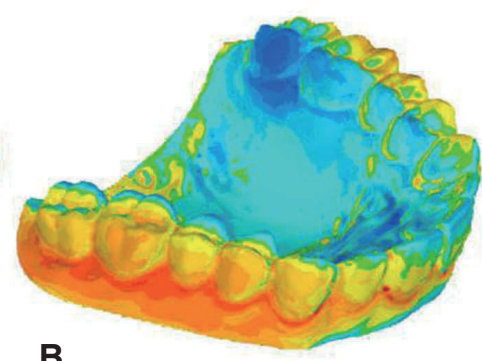

B

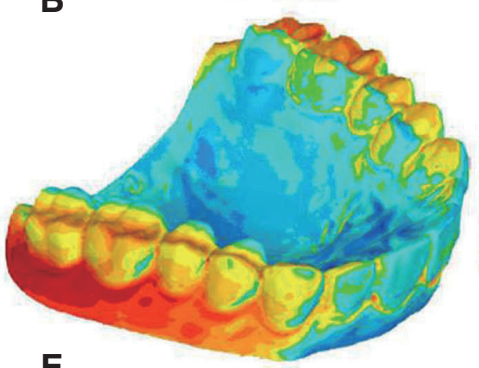

E

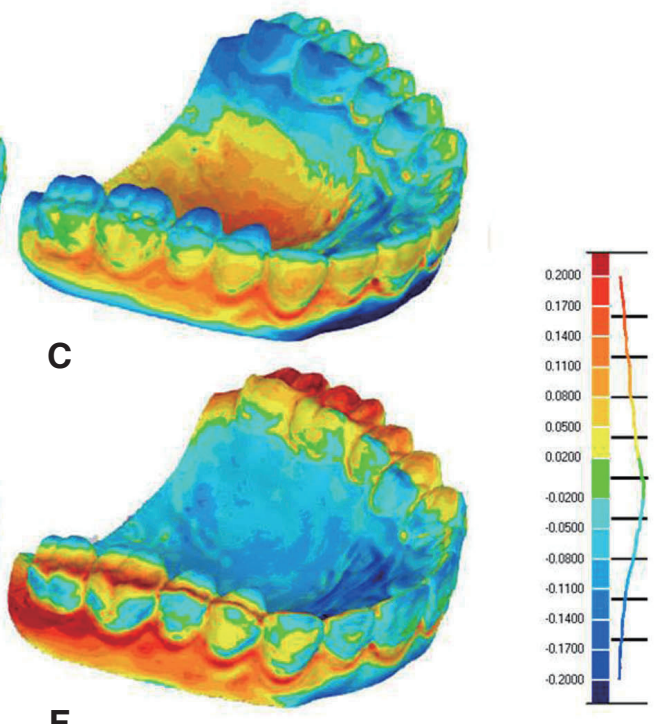

$\mathbf{F}$

Fig. 6. Maxillary surface deviation of stone pouring time on relative humidity $35 \%$ air. (A) Immediately, (B) 10 minutes, (C) 30 minutes, (D) 60 minutes, (E) 180 minutes, (F) 360 minutes.

2) 하악 모형

하악 주모형과 각 실험군의 삼차원 디지털 모형을 중 첩한 결과, 알지네이트로 인상 채득 즉시 석고 모형을 제작한 경우 표면 변위량은 $0.02 \mathrm{~mm}$ 로 가장 낮게 나타 났다. 석고 주입 시간에 따른 결과에서 시간에 따라 표 면 변위량은 증가하며, $100 \%$ 상대습도의 항습조에 보
관한 경우가 $35 \%$ 상대습도의 공기 중에 보관한 경우에 비해 표면 변위량이 모두 낮게 나타났다. 표면 변위가 상악에서는 주로 제 2 대구치의 협측 치은부위에 발생하 였고, 하악에서는 시간이 경과할수록 전치부쪽으로 변 위가 증가하였고, 전체적으로 치아의 순측과 협측에는 팽창, 설측과 절단연에는 수축이 발생하였다(Fig. 7-9). 


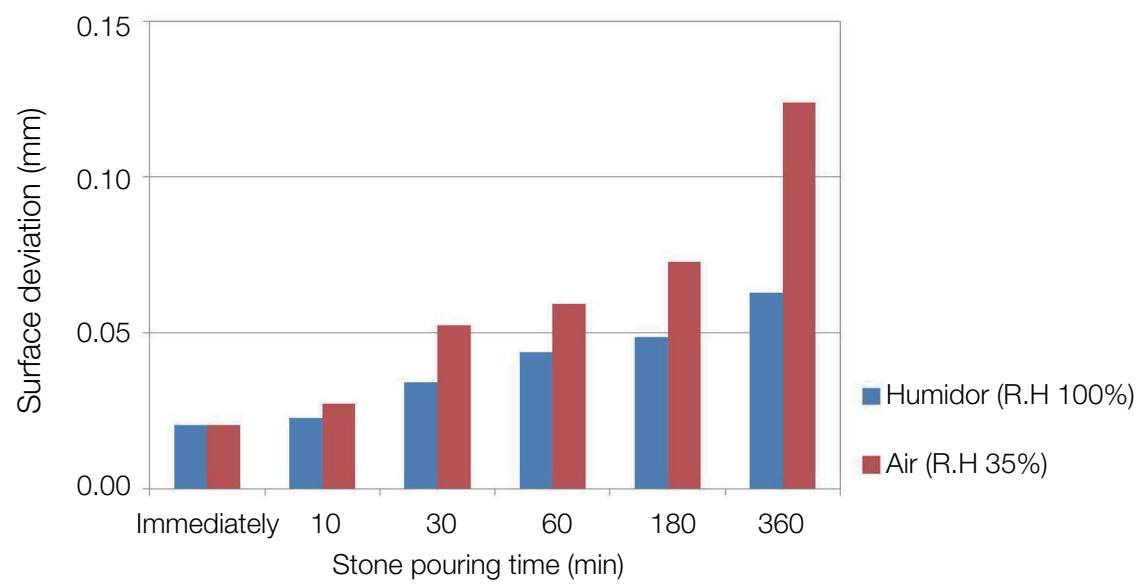

Fig. 7. Mandibular surface deviation according to storage condition and stone pouring time. R.H, relative humidity.

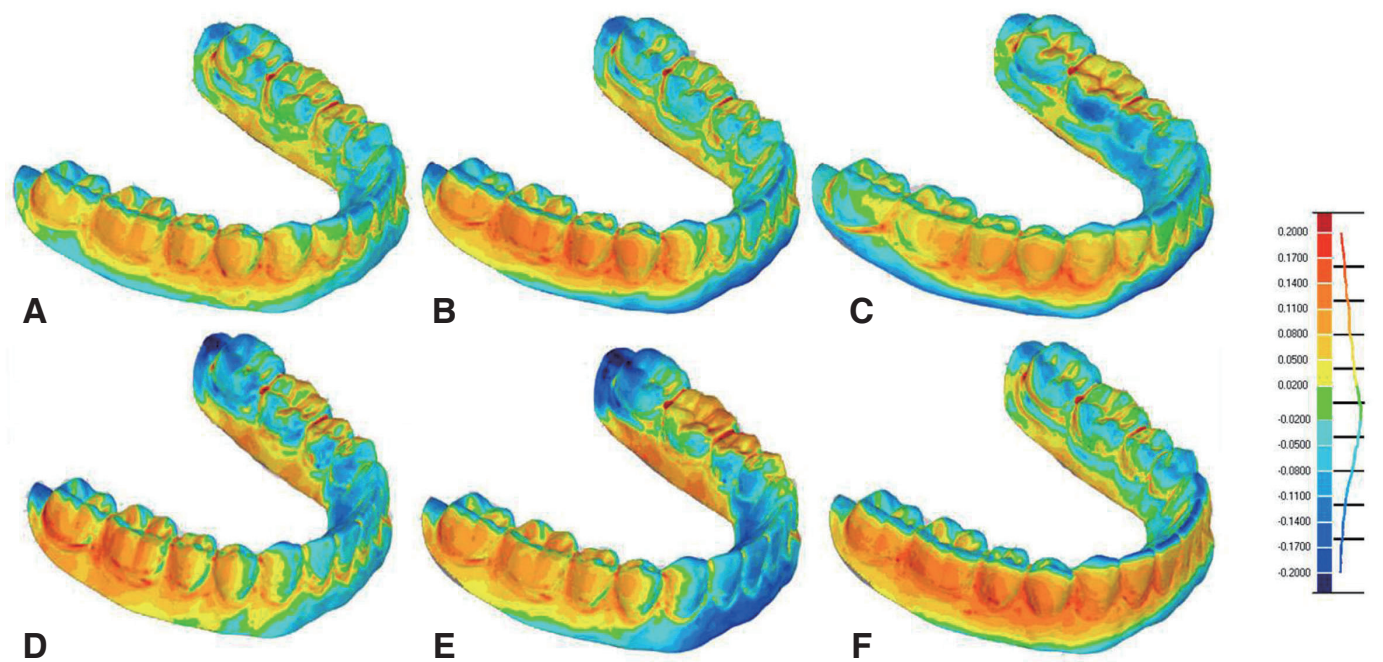

Fig. 8. Mandibular surface deviation of stone pouring time on relative humidity $100 \%$ humidor. (A) Immediately, (B) 10 minutes, (C) 30 minutes, (D) 60 minutes, (E) 180 minutes, (F) 360 minutes.

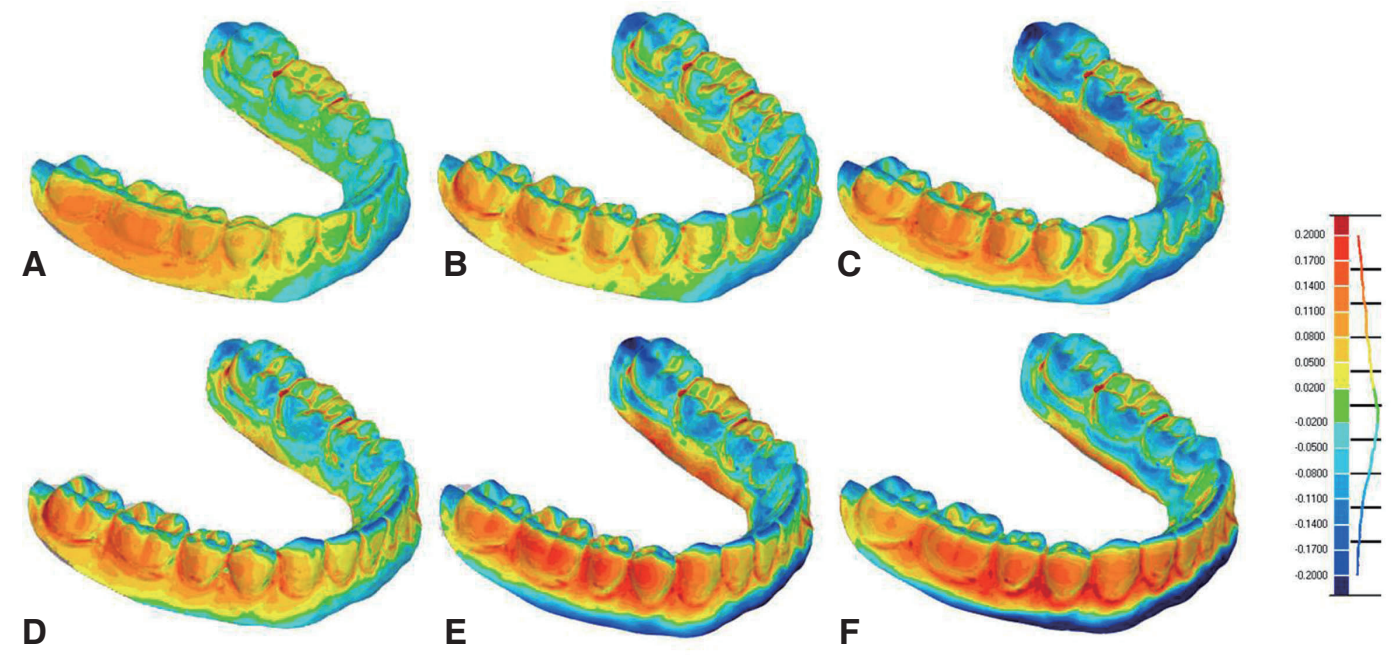

Fig. 9. Mandibular surface deviation of stone pouring time on relative humidity $35 \%$ air. (A) Immediately, (B) 10 minutes, (C) 30 minutes, (D) 60 minutes, (E) 180 minutes, (F) 360 minutes. 


\section{고찰}

콜로이드는 분자들 또는 분자 군이 모여 덩어리를 이 룬 것의 현탁액을 말하며 일종의 분산용액이다. 콜로이 드는 분산 입자들과 분산액의 두 가지 상이 존재한다. 하이드로콜로이드란 용어는 분산액이 물인 경우이며, 물이 기본이 되는 인상재를 하이드로콜로이드 인상재라 고 한다. ${ }^{18}$ 그러므로 하이드로 콜로이드 인상재는 인상 체 내부의 수분의 변화에 의해 안정성이 변화할 수 있기 때문에 인상재의 혼합, 혼합 방법, 채득된 인상체의 보 관 조건이나 석고 주입 시간에 따라 크기 안정성에 영향 을 받을 수 있다.

본 실험에서는 보관 조건과 석고 주입 시간을 변수로 하여, 실험의 변수 외에는 동일한 조건이 되도록 하였 다. 인상재의 혼합은 제조사의 지시에 따라 혼수 비에 맞추어 동일한 알지네이트 분말과 계량된 물을 사용하 였고, 알지네이트 인상재를 혼합과정에서 일정한 혼합 시간(14초)과 균일한 혼합을 위해서 알지네이트 인상재 진공혼합기를 이용하였다. 알지네이트는 손으로 혼합할 때에 비하여 진공혼합기의 인상재가 더 균질 하게 혼합 되기 때문에 공기유입이 적고 경화시간이 더 일정하며, 탄성회복과 인장강도가 증가하게 된다. ${ }^{19}$ 인상 채득에서 트레이의 선택도 모형의 정확성에 영향을 미친다. 본 실 험에서는 진료실에서 알지네이트 인상 채득 시에 기성 금속 트레이를 사용하기 때문에 동일한 조건의 트레이 를 사용하였다. 기성 금속 트레이를 이용하는 경우 치아 와 알지네이트의 간격이 일정하지 않고, 상악의 구개부 위에서는 다른 부위에 비해 간격이 클 수 있다. Frank 등 ${ }^{20}$ 은 알지네이트 인상재를 사용하는 경우에는 상악의 구 개부에서 개인 트레이를 이용하여 일정한 두께를 유지 하는 것과 기성 트레이를 사용하는 것에 유의한 차이를 보이지 않는다고 하였다. 일반적으로 탄성 인상재는 일 정한 두께를 갖도록 제작된 개인 인상용 트레이를 사용 하는 경우에 정확한 인상이 채득되지만, 알지네이트 인 상재는 두꺼운 인상체가 더 큰 표면적 대비 체적의 비율 을 갖기 때문에 크기 변화를 야기하는 이액과 팽윤에 덜 민감하게 되기 때문이다. ${ }^{18}$

인상 채득 과정에서 알지네이트 인상재가 겔화 되는 동안 트레이가 움직이는 경우, 트레이 내에 인상재를 부 적절하게 유지시키는 경우, 채득된 인상체를 제거하는 방법이 잘못된 경우에도 부정확한 석고 모형이 제작될 수 있다. ${ }^{1}$ 그러므로 본 실험에서는 알지네이트 인상제가
경화되는 시간 동안 트레이가 주모형과 일정한 간격을 유지하면서 움직이지 않도록 인상 채득 장치를 제작하 여 실험을 진행하였다. 인상 채득 장치는 전방과 후방에 인상용 금속 트레이가 동일한 위치에 고정되도록 하며, 나사로 고정이 되어 알지네이트 인상재가 동일한 압력 을 유지하면서 경화될 수 있기 때문에 인상 채득 과정의 일관성을 유지할 수 있도록 하였다.

알지네이트 인상재는 임상에서 많은 장점을 가지고 있고, 또한 가장 많이 사용되는 인상재이다. 모형의 부 정확성은 인상재 자체의 문제가 아닌 사용자의 적절한 조작과 보관이 이루어지지 않았을 경우에 발생한다. ${ }^{21}$ 가장 정확한 모형을 얻기 위해서는 채득된 알지네이트 인상체 내로 석고 주입을 가급적 빨리 시행하는 것이다. 임상에서 발생하는 여러 가지 상황으로 인해 석고 주입 을 바로 시행하지 못할 경우에는 $100 \%$ 상대습도가 유 지될 수 있도록 항습조에 보관해야 한다. 알지네이트 인 상체의 변형이 발생할 수 있는 가장 큰 요인은 석고 주 입 시간이 지체되는 경우이다. ${ }^{22}$ 본 연구의 결과에서도 모형의 각 참고점에서의 측정치를 기준으로 계산된 변 형률은 인상 채득 즉시, 석고를 주입한 경우가 가장 낮 게 나타났고, 디지털 삼차원 중첩을 통한 표면 변위량 에서도 가장 작은 값을 나타냈다. 인상 채득 과정에서 알지네이트 인상재는 치아와 조직부위의 언더컷과 채 득 방법에 따라 압축력에 의한 변형이 발생한다. 알지네 이트는 탄성 인상재로 인상 채득 후에 탄성회복이 나타 나지만, 영구변형이 발생되게 된다. 국제표준규격에서 는 영구 변형률을 $5 \%$ 이하로 규정하고 있다..$^{22}$ 본 실험 에서 변형률은 대부분의 참고점에서의 거리는 $5 \%$ 이하 로 나타났다. 그러나 하악 제 1 대구치에서 석고 주입시 간이 180 분 이상일 경우에 보관 조건에 관계없이 $5 \%$ 이 상의 변형률을 보였고, 공기 중에 보관된 인상체에서 석 고 주입 시간이 6시간일 때 제 1 대구치에서 $6.55 \%$ 로 가 장 높은 변형률을 나타냈다. 견치 간 거리, 제1대구치 간 거리, 제 2 대구치 간 거리와 같이 수평적인 길이에서 는 기존의 연구와 유사한 $1 \%$ 이내의 변형률을 보였다. ${ }^{23}$ Nassar 등 ${ }^{24}$ 의 연구에서는 수평적인 길이의 변형률을 측 정하였기 때문에 $0.5 \%$ 이내의 변형률을 보이는 4 시간 까지 지연된 석고 주입 시간이 허용된다고 하였으나. 대 구치의 높이 변형률을 측정한 본 연구의 결과를 따르면 석고 주입 시간은 180 분을 넘지 않아야 할 것으로 사료 된다. 임상적으로 발생할 수 있는 여러 가지 변수가 존 재하고, 모형이 사용되는 진료의 목적이 다르기 때문에 
임상적으로 허용할 수 있는 최대 크기 변화량은 특별하 게 제시된 기준이 없다. 그러나 최적의 정확성을 얻기 위해서는 가급적 인상 채득 후에 즉시 모형을 제작하는 것이 추천된다.

기존의 연구에서 인상재의 크기 안정성을 평가하는 방법은 주로 인상체에 석고를 주입하여 모형을 제작하 고 모형 상의 참고점에서 거리를 측정하는 방식이었 기 때문에 변형률을 평가할 수는 있지만 변형이 발생 된 부위와 크기는 확인이 어려운 제한 점이 있었다. ${ }^{12-16}$ 본 실험에서 사용된 3D metrology software (Geomagic Control, 3D Systems)는 삼차원 모형 스캐너로부터 획 득된 점군데이터를 기반으로 다양한 단면을 분석하는 것이 가능하고, 수동 반복 측정 오류를 감소시켜 측정의 질을 향상 시킬 수 있다. 또한 기준 모형과 실험군의 모 형을 중첩을 통하여 삼차원적 평가가 가능하고, 편차를 색깔로 표시하여 시각화가 가능하기 때문에 변형 발생 한 표면의 차이를 확인하는 것이 용이하다. ${ }^{25}$ 본 실험에 서는 중첩으로부터 확인할 수 있는 주모형과 실험군 모 형의 차이는 표면 변위량으로 평가하였고, 표면 변위를 보인 부위를 확인 하였다. 이러한 방법은 임상에서 모형 이 사용될 때 전체 부피의 변화에 의해 생기는 변형률을 확인 하는 방법보다 더 임상에서 효과적으로일 것으로 사료된다.

상악과 하악 모두에서 표면 변위는 석고 주입 시간이 경과하여 보관시간이 증가할수록 표면 변위량은 점차 증가하였고, 항습조에 보관한 모형이 실험실 공기 중에 보관한 모형보다 표면 변위량이 적었다. 상악의 경우에 는 주로 시간의 경과에 따라 대구치부위의 변위량이 증 가하였으며, 하악의 경우에는 전치부의 순면과 구치부 의 협면을 따라 변위량이 선상으로 나타났다. 또한 거리 측정에 따른 결과에서 제 1 대구치와 제 2 대구치의 치관 높이는 석고 주입 시간에 따라서 통계적으로 유의한 차 이를 보였다. 중첩에 따른 결과에서 상악은 180 분이 경 과하면 보관 조건에 관계없이 교합면에 변화가 증가하 기 시작하고 360 분이 경과하면 제 1,2 대구치에 표면 변 위가 $200 \mathrm{um}$ 까지 변화하게 되므로 대합치로 사용되는 모형의 경우에는 교합관계의 변화를 야기하여 수복물의 정확성에 영향을 미칠 수 있게 된다. 참고점에서의 길 이 측정과 디지털 모형의 중첩을 통하여 표면 변위량 측 정을 시행한 이번 실험에서 이차원적인 수평 길이 변형 률이 작을 지라도 모형의 삼차원 표면 변위는 발생하며, 특히 표면 변위가 대구치부위에서 발생하기 때문에 모
형의 대합관계에 영향을 미치게 된다. 환자의 구강 내에 서 채득된 인상체로부터 최적의 정확성을 갖는 모형을 제작하기 위해서는 즉시 석고를 주입한다. 보관이 필요 한 경우에는 $100 \%$ 상대습도가 유지되는 항습조에 보관 하며, 석고 주입 시간은 180 분을 넘지 않도록 하는 것이 필요할 것으로 사료된다.

본 실험은 인상을 채득 한 후에 보관 조건과 석고 주 입 시간에 따라 제작된 모형의 정확도를 평가하였다. 그 러나 진료실에서는 교차 감염을 방지하기 위해서 시행 되는 인상체의 세척과 감염 관리 과정을 시행하고 있고, 미국치과의사협회에서는 인상체를 30 분 이내의 화학 소독제를 이용하여 침적 소독하는 방법을 권장하고 있 다. ${ }^{26}$ 본 실험에서는 이러한 감염 관리 과정이 고려되지 않았기 때문에 향후 진료실에서 행해지는 침적 소독 후 에 알지네이트 인상체로부터 제작된 모형의 정확성에 대한 연구가 추가로 필요할 것으로 사료된다.

\section{결론}

본 연구는 보관 조건과 석고 주입 시간에 따라 알지네 이트 인상체로부터 제작된 모형의 정확성을 알아보고 자 하였다. 채득된 인상체는 $100 \%$ 상대습도가 유지되 는 항습조에 보관하는 것과 진료실 내의 공기 중에 노출 되는 상태로 보관 조건을 달리하였다. 보관 조건에 따라 각각 즉시, 채득된 후 10 분, 30 분, 180 분, 360 분으로 나 누어 보관한 후에 석고 모형을 제작하였다. 제작된 석고 모형을 $3 \mathrm{D}$ 레이저 스캐너로 삼차원 디지털 모형을 구성 하였고 구성된 디지털 모형의 참고점에서 거리를 측정 하여 변형률을 비교하였다. 또한 각 실험군의 삼차원 디 지털 평균 모형을 제작한 후 중첩을 시행함으로써 표면 변위가 발생한 부위와 크기를 확인하여 다음과 같은 결 론을 얻었다.

1. 인상 채득 즉시 제작한 모형의 변형률이 가장 작게 나타났다.

2. 공기 중에 보관한 인상체보다 항습조에 보관한 인 상체의 변형률이 작게 나타났다.

3. 석고 주입 시간이 증가함에 따라서 변형률은 증가 하였다.

4. 석고 주입 시간이 180 분을 지나면 보관 조건에 관 계없이 대구치 부위에서 변형률과 표면 변위가 증 가한다. 
이상의 결과에서 알지네이트 인상체로부터 제작된 모 형의 정확성을 위해서는 인상 채득 후, 즉시 모형을 제 작해야 한다. 보관이 필요한 경우에는 $100 \%$ 상대습도 가 유지되는 항습조를 이용하고, 보관 시간은 180 분을 넘지 않도록 해야 정확한 모형을 얻을 수 있다.

\section{Acknowledgements}

본 연구는 2014년 원광대학교 교내 연구비 지원에 의 해 이루어졌음.

\section{References}

1. Anusavice KJ. Phillips' science of dental materials. 12th ed. St. Louis; Elsevier Inc.; 2013. p. 171-6.

2. Rubel BS. Impression materials: a comparative review of impression materials most commonly used in restorative dentistry. Dent Clin North Am 2007;51:629-42.

3. Donovan TE, Chee WW. A review of contemporary impression materials and techniques. Dent Clin North Am 2004;48:445-70.

4. Nandini VV, Venkatesh KV, Nair KC. Alginate impressions: a practical perspective. J Conserv Dent 2008;11:37-41.

5. Cook W. Alginate dental impression materials: chemistry, structure, and properties. J Biomed Mater Res 1986;20:1-24.

6. Sedda M, Casarotto A, Raustia A, Borracchini A. Effect of storage time on the accuracy of casts made from different irreversible hydrocolloids. J Contemp Dent Pract 2008;9:59-66.

7. Rudd KD, Morrow RM, Bange AA. Accurate casts. J Prosthet Dent 1969;21:545-54.

8. Eissmann HF, Rudd KD, Morrow RM. Diagnostic procedures. In: Dental laboratory procedures: fixed partial dentures. Vol. 2. St. Louis; Mosby; 1980. p 1-29.

9. Erbe C, Ruf S, Wöstmann B, Balkenhol M. Dimensional stability of contemporary irreversible hydrocolloids: humidor versus wet tissue storage. J Prosthet Dent 2012;108:114-22.

10. Walker MP, Burckhard J, Mitts DA, Williams KB. Dimensional change over time of extended-stor- age alginate impression materials. Angle Orthod 2010;80:1110-5.

11. Nassar U, Aziz T, Flores-Mir C. Dimensional stability of irreversible hydrocolloid impression materials as a function of pouring time: a systematic review. J Prosthet Dent 2011;106:126-33.

12. Johnson GH, Craig RG. Accuracy of four types of rubber impression materials compared with time of pour and a repeat pour of models. J Prosthet Dent 1985;53:484-90.

13. Wadhwa SS, Mehta R, Duggal N, Vasudeva K. The effect of pouring time on the dimensional accuracy of casts made from different irreversible hydrocolloid impression materials. Contemp Clin Dent 2013;4:313-8.

14. Cohen BI, Pagnillo M, Deutsch AS, Musikant BL. Dimensional accuracy of three different alginate impression materials. J Prosthodont 1995;4:195-9.

15. Oh NS, Seo JM, Kim SH, Youn YA, Shim JS. Agaralginate combined impression technique and dimensional change resulting from idophor disinfection. J Korean Acad Prosthodont 2004;42:21-9.

16. Alcan T, Ceylanoğlu C, Baysal B. The relationship between digital model accuracy and time-dependent deformation of alginate impressions. Angle Orthod 2009;79:30-6.

17. Sousa MV, Vasconcelos EC, Janson G, Garib D, Pinzan A. Accuracy and reproducibility of 3-dimensional digital model measurements. Am J Orthod Dentofacial Orthop 2012;142:269-73.

18. Roesnstiel SF, Land MF, Fujimoto J. Contemporary fixed prosthodontics. 4th ed. St. Louis; Mosby; 2006.

19. Dreesen K, Kellens A, Wevers M, Thilakarathne PJ, Willems $G$. The influence of mixing methods and disinfectant on the physical properties of alginate impression materials. Eur J Orthod 2013;35:381-7.

20. Frank RP, Thielke SM, Johnson GH. The influence of tray type and other variables on the palatal depth of casts made from irreversible hydrocolloid impressions. J Prosthet Dent 2002;87:15-22.

21. Ashley M, McCullagh A, Sweet C. Making a good impression: (a 'how to' paper on dental alginate). Dent Update 2005;32:169-70, 172, 174-5.

22. Sakaguchi RL, Powers JM. Craig's restorative dental 
materials. 13th ed. Philadelphia; Elsevier Inc; 2012.

23. Song KY, Yang JH, Lee SH, Chung HY. A study on dimensional stability of impression materials following immersion disinfection. J Korean Acad Prosthodont 1999;37:506-15.

24. Nassar U, Hussein B, Oko A, Carey JP, Flores-Mir C. Dimensional accuracy of 2 irreversible hydrocolloid alternative impression materials with immediate and delayed pouring. J Can Dent Assoc 2012;78:c2.
25. Teeter MG, Naudie DD, McErlain DD, Brandt JM, Yuan X, Macdonald SJ, Holdsworth DW. In vitro quantification of wear in tibial inserts using microcomputed tomography. Clin Orthop Relat Res 2011;469:107-12.

26. ADA Council on Scientific Affairs and ADA Council on Dental Practice. Infection control recommendations for the dental office and the dental laboratory. J Am Dent Assoc 1996;127:672-80. 


\section{알지네이트 인상체에서 제작된 치과용 석고 모형의 정확도에 대한 삼차원 디지털 분석}

주용훈, 이진한*

원광대학교 대전치과병원 보철과

목적: 보관 조건과 석고 주입 시간에 따라 알지네이트 인상체로부터 제작된 모형의 정확성을 알아보고자 하였다.

연구 재료 및 방법: 채득된 알지네이트 인상체는 습도가 유지되는 항습조에 보관하는 것과 진료실 내의 공기 중에 노출 되는 상태로 보관 조건을 달리하였다. 보관 조건에 따라 각각 즉시, 채득된 후 10 분, 30 분, 180 분, 360 분으로 나누어 보 관한 후에 석고 모형을 제작하였다. 제작된 석고 모형을 $3 \mathrm{D}$ 레이저 스캐너로 삼차원 디지털 모형을 구성하였고 구성된 디지털 모형의 참고점에서 거리를 측정하여 변형률을 비교하였다. 또한 각 실험군의 삼차원 디지털 평균 모형을 제작 한 후 중첩을 시행함으로써 표면 변위가 발생한 부위와 크기를 확인하였다.

결과: 인상 채득 즉시 제작한 모형의 변형률이 가장 작게 나타났고, 공기 중에 보관한 인상체보다 항습조에 보관한 인 상체의 변형률이 작게 나타났다. 석고 주입 시간이 증가함에 따라서 변형률도 증가하였으며, 석고 주입 시간이 180분 을 지나면 보관 조건에 관계없이 대구치 부위에서 변형률과 표면 변위가 증가한다.

결론: 알지네이트 인상체로부터 제작된 모형의 정확성을 위해서는 인상 채득 후, 즉시 모형을 제작해야 한다. 보관이 필요한 경우에는 $100 \%$ 상대습도가 유지되는 항습조를 이용하고, 보관 시간은 180 분을 넘지 않도록 해야 정확한 모형 을 얻을 수 있다.

주요어: 알지네이트 인상체; 체적안정성; 삼차원 중첩 